\title{
Conversations on Citizenship, Critical Hope, and Climate Change: An Interview with Bronwyn Hayward
}

\author{
Bronwyn Hayward and Sara Tolbert
}

Sara Tolbert: Thank you so much for agreeing to do this interview, Bronwyn. I know I've told you a bit about the book, and how we are bringing together scholars, activists, and educators who are thinking about and interested in education in and for the Anthropocene. I've been editing a section on vectors of power and am very interested in your work as a political scientist, particularly the work that you've done with social agency and trying to bring more attention to youth voice and other areas of ecological citizenship.

Bronwyn Hayward: Ah, fantastic. I just had to write a blurb for Mike Hulme, who wrote the book, Why We Disagree about Climate Change. He's a climate scientist. He's been around for a long time. He's just bringing out a new book, Climate Change. His argument is that we have to move beyond the science, but he structures the science in a really interesting way that makes you think about "thin environmentalism" and modernism. But then he looks beyond that to Indigenous writing and feminist writing and artists to join the push back on the [prevailing narratives about how] "there is no time left" and "it's all going to end" to "we're actually going to live in a changing climate"... we always have-it's going to be difficult and different, but it's going to be diverse and the scientists don't get "The Say" in this. It's very interesting.

B. Hayward $(\varangle) \cdot S$. Tolbert

University of Canterbury, Christchurch, New Zealand

e-mail: bronwyn.hayward@canterbury.ac.nz

S. Tolbert

e-mail: sara.tolbert@canterbury.ac.nz 
Sara: It is, I mean, that's a really interesting point. I think my co-editors and I have all been really situated in that space of understanding, but also moving with and beyond, the science. Kind of like expanding the boundaries of what you know, what we even call science, and who gets to be seen as qualified to have a perspective. Not only science, but even in science education, we do that a little bit, too, to each other. And I wondered, what you see, as a political scientist, as the relationship between political science and science because you do a lot of work on the IPCC with scientists and you have to try to have those transdisciplinary conversations. What do you see, given your role on IPCC and given your positionality as a political scientist-how do you see those relationships? And what do you think is working well and in those collaborations in that space? And what needs to change?

Bronwyn: I can say for me, I've found working on the Intergovernmental Panel for Climate Change [IPCC] has been really empowering for several reasons. First, you're working with whole teams, huge teams of people, who are concerned and interested in the issues, and that really creates a sense of purpose. And we talk about how empowering it is for children and young citizens, to have a sense of collective agency, when there are many of you working together to effect change on complex issues, but it's also been really true for my experience on the IPCC. It's not that we expect to save the world one citation at a time. But you do feel like you're a small part of a much wider project to tackle the underlying drivers of climate change, but also to document and bear witness to the changes that are happening. So that's the first part.

The second part, I think, is that it is quite confronting as a political scientist to work with other scientists on a complex wicked problem. Because I think in the social sciences, we often assume that the problem lies with the sciences, if only they [scientists] would be more open to our reasoning, if only they would accept wider knowledge and other perspectives. I think what has been important for me to understand is that some of the biggest battles that I have with the discipline boundaries that police who's allowed to talk about what and how an issue is framed are actually with my social science colleagues. They have more astute language to obscure the power plays, but there's a definite policing of what happens, and who's allowed to say what. And in many ways, working with natural and physical scientists is quite refreshing because they just ask questions like, "why do you think that is?" because they are based on observation, often, and trial and error. They're often just interested in other ways of understanding problems. And I think that's a bit salutary to think that the social sciences are part of the problem of why we can't collaborate very well, that we're very defensive often and we're quite determined to frame the problem, that we [also think we] have "The Way" of framing the problem. So bringing a bit of humility into research is quite interesting. And it's quite important, I think, especially on these big projects and big problems.

I think the third feature is that, while the IPCC works very hard to be policy relevant but not policy prescriptive, meaning they don't try to give 
governments "advice" because the governments will sign off [i.e., approve, or not] the final reports, politics are imbued in all processes. And I think as a political scientist, one of the things I am conscious of is, as are many colleagues, is to avoid self-censoring because an option may not be accepted by governments, but where there are deep value applications in the options that we're offering - and to notice sometimes if you're not trained or not thinking about how power affects people and communities and non-human nature, you just don't notice it, or you're not aware of it.

Sara: It makes me think about some of the more recent work that we've been talking about in terms of working across these diverse socio-climatic nexuses, looking at working across interest groups or different stakeholders that might not necessarily see themselves as working together. But part of this idea of, as you said, living as well as we can together in the context of climate change and whatever language you want to use, "on a damaged planet," let's say, does kind of require this sort of forging of new collaborations... and new solidarities-like with the Federation of Farmers, for example, that we've been talking about, so across scientists and iwi [tribes] and bringing communities in conversation together. And that's been an aspect of some of your recent work. Can you say a little bit about that?

Bronwyn: Well, I do think that Michael Hulme (2021) in his book on climate change puts it really well. When he says that there are a multitude of experiences of climate change and climate change is a complex series of problems. It's not a single problem and it's not a single experience-that it's not something that we are all in together. I think one of the problems about why it's been hard to get collective solidarity to address climate change is that our changing climate is experienced as weather in different ways in local communities, over time, so it's not like a global pandemic where everybody is experiencing an acute risk at the same time. Instead you're having some communities exposed to extensive storms and others to extended droughts and a lot of the suffering and a lot of the problem solving is at local community level and requires the nuance and understanding of local issues, and is also subjected to power imbalances and ways of framing the problem and how the story is told to others. So I think there is a real role for researchers and storytellers and community advocates to do the connecting so that people can understand how their experiences in one time and place are connected to and influence the experiences of others. And Occupy and those kinds of movements, and the School Strike movement actually, have created that sense of a shared experience, even though our local experiences of climate change are really different. We share some key concerns, and those can be articulated as a larger narrative, even though the local experiences are going to be really diverse.

Sara: So you mentioned School Strike 4 Climate as a recent example. I think there's a lot of interest in what's going on there because it's youth-led and has some parallels to youth-led movements in the sixties. How did you 
become involved in that movement because I know you were the only adult [speaker] at the school strike for climate demonstration last March (2019)?

Bronwyn: I was very honored to be the token adult. Actually, I don't know how I was invited. They just emailed me. Some of their mums and some of the students knew about the Children, Citizenship, o Environment book. And some of them have been my students, some of the organizers were former students. And I think that's how it came about, really, from teaching. So it was a lovely connection. And the fact that it happened on the day of the mosque terror attacks [in Christchurch, 15 March 2019], and all of those issues collided, is a reminder that this generation and the ones that follow are dealing with such complexity. And so many layers of challenge of social and economic and inequality and racial and identity challenge all at the same time. I find it really important that we support their capabilities to cope in what will be almost a sped up hyper-reality of these colliding issues because our global connections are so much closer, our ways of communicating so much more rapid and far-reaching, that many of the problems that we have built up over the centuries, like colonization, racism, gender inequality, our changing climate, are all kind of coalescing in... moments in time. Now much faster even than they were in the Sixties in the civil rights movements because our communication is just that much faster and so much more personalized into people's homes and their phones and their Facebook messaging. So I think having the skills and capacity to cope with that is really important.

Sara: Could you talk a little bit about more about what you mean about their abilities to cope? Because you've written a lot about that and I think it's very useful for educators.

Bronwyn: I've been really interested in how we maintain democracy through disaster and change, over time, as a political scientist. Originally, my work on Children, Citizenship, \& Environment: Nurturing a Democratic Imagination in a Changing World, the reason that that started was because I was asked by the New Zealand Electoral Commission to do a small study on why kids aren't voting. And why young people aren't voting. And I had wanted to do some interviews with eight to twelve year olds, sort of that time of a rising sense of citizenship and community. What really struck me is fascinating because I was also interested in environment and geography as well, is that when we talk to people about what do they do around here, what do they like to do with other people, actually their physical environment and their experiences of their social and natural world collided with their understandings of what it was to be a citizen in very holistic and rich and deep ways for every child that we interviewed. And so what began as a study of just "what do young people think about voting?" rapidly became "how do young people learn to feel that they are part of a community and can effect change?" And that communities have a right to be heard because we know that a lot of the reasons that youth aren't voting really is not the problem of a deficit of information or a deficit, period. 
It's the series of suppression effects that we do in different societies. Even repeating the argument that young people are apathetic or aren't interested or that they can't vote then reinforces a kind of a disjuncture with voting. But when they're in contexts in which they're talking about issues that matter for the community and the world around them, then they're very strongly motivated to have a say when they're supported. And I was also very struck by the really practical, physical, emotional, and social factors in whānau [extended family] and family in neighborhoods and schools that restrict and reduce children's voice. And understanding whether it's fear of physical violence at home, whether it's lack of money and feeling shamed to speak out, whether it's feeling not worthy. So that's what I was interested in, I sort of rapidly found a way to draw together the two things that I love, you know, how is it that we maintain democracy, and how is it that we experience and understand our natural world and support it. Because actually in real life, we do those things together all the time. We just separate them when we're researching them. So that got me thinking about the fact that a lot of our teaching goes in two directions. And this was before Trump. But back in 2012. Because of the barriers that children were experiencing and reporting just here and in my local city and the hugely diverse experiences of participation [children were experiencing], I started thinking about what suppresses their voice and their opportunities to engage. So what political power do kids experience that silences them? And that's what I described as the "FEARS" of citizenship [(Hayward, 2012, 2020)]. It's almost a pathology of experiences and where you feel frustrated about your lack of agency and not able to express yourself because of fear of being hurt. It's a very basic fear of speaking out or lack of money. And when you are excluded from the environment around you. We're building walls, whether it's just fences to constrain where children can play, and very strict limits on what they can do, where they can be-seen and not heard. But also, not even physically in spaces that are increasingly being securitized and kind of semi-public private spaces and the way that we encourage a very basic sense of retribution of justice, the eye for the eye, and find someone to blame. And it's all very simple. You direct your anger and feelings of helplessness to another group or organization or individual that you can blame. And its effect is we see very low participation in formal voting and we have a really kind of silenced sort of political imagination.

When we're teaching environment, we risk the same kind of participation because we reinforce this kind of "SMART" way of thinking about the environment [(Hayward, 2012, 2020)], which I would argue is quite a thin approach to environmentalism, where there's a lot of emphasis on the selfhelp and self-responsibility of individuals, which is great, but it leaves that anxious and overwhelmed child unsupported. There's enormous influence on participating in the market. So you express your sense of citizenship through doing things like buying eco-products or creating sustainable new innovative products that you can sell as an entrepreneur. And if you are a good, smart environmental citizen, then your ideas about justice are very contractual. Like 
we encourage a lot of a priori reasoning, because we want the market to work well and we want what's fair in a market sense, so we encourage young people to think about, "I will do my bit if you do yours." There is no sense of "we're doing the right thing in the current situation," but it's more contractual justice. We teach a lot of that in classrooms. We set up what our classroom justice is going to be, and we expect children to do it. As teachers, what we're also setting them up for is to understand how the market will work in the future because we're expecting people to behave in particular ways. In one sense, their political imagination is very transformative. So we're looking at developing new technologies that are solar powered, that are low carbon, that are innovative. And we want them to vote for and be good citizens, voting for representatives that are going to speak for us.

And there's nothing wrong with all of that, but it leaves unquestioned and unchallenged the underlying drivers of our climate problems. For example, the social inequalities, the economic growth models, the consumption models are not really questioned-what's driving it [climate change]. It is terribly important that we have individuals who care and take responsibility and take action, but in these conflicts, wicked huge global problems, it is overwhelming. And that's where we see very anxious children. People who feel that they just can't cope or that they could just pay and that would solve the problem. So, in thinking about that, I was thinking, well, that is the classic neoliberal citizen, but it doesn't explain everything that we were seeing when we were interviewing children just in the city.

And we did also interview children up in the north of New Zealand as well because we just worked with a research team who went home to their own primary schools, but what we also saw was this kind of resistance where children were not just thinking as individuals, they were learning social agency, and they were learning that through participation in school camps, in choirs, through their iwi, through kapa haka, they were learning to be part of a collective. And those skills of the collective come out in things like the Student Volunteer Army [a collective of student volunteers that formed a disaster response team in post-earthquake Christchurch, 2011, and then became institutionalized, https://sva.org.nz/our-story/]. I mean, it just doesn't happen that everyone collaborates if they haven't been nurtured and encouraged and socialized to collaborate as a norm in response to shared problems or risks. And we also saw a strong sense of embedded justice, the ability to be able to reason about what's fair in place. A lot of children could tell you that it was unfair that something [e.g., such as a disciplinary action] had happened to one of the kids in their class because they knew the conditions or issues that were facing that child. So children and young people can be very reasonable if they're encouraged to think about-not just if you fail to meet expectationsbut actually we live in a messy world, how can we do the right thing over time, understanding the impacts of colonization and gender violence and all the things that shape the trauma and the lives that we live. 
For me, environmental education is more than just the science. The science is deeply important but the children who had a strong sense of being able to participate in their environment and effect change had some connection to it as well. So often, they had a sense of tūrangawaewae ["a place to stand" or empowerment]. That might be their local marae [communal or sacred place] or it might be their local neighborhood that they had grown up with, where they enjoyed and found a restful and emotional connection with that space. And also when there's an opportunity to decenter deliberation so that children are not just overwhelmed with their own local experiences but are able to put it in context through storytelling is really basic, and, for example, you just look at common children's stories like Winnie the Pooh (Milne \& Shepard, 1994). When you actually look at that as an English narrative, there's a lot embedded in there that's talking about how children deal with large social environmental change that's beyond their immediate capacity to control, whether it's a big flood or the big wind or somebody leaving home that they weren't expecting. And then that sense of self-transcendence, so how young citizens are supported to do and be in the context of a history of what's gone before and a feeling of what might be to come. And sometimes that's achieved through strong spiritual values, but often it's achieved, we noticed, by children who feel that they are part of something that grandparents have worked for. For instance, Ngāi Tahu young people, many who are taught within bilingual schools [i.e., kura kaupapa Māori], are very aware of generations working for Te Tiriti o Waitangi [The Treaty of Waitangi] settlement. Others are aware of their parents and grandparents, having made changes and that sense that you're able to defer not only immediate gratification, but to understand that change takes time and happens across generations. It's not just all down to you.

Sara: I think that's really important, I mean for my perspective, working with preservice teachers and helping them unpack some of the ways in which they've learned about the environment. And taking a deconstructive approach to that. It's really interesting seeing how they peel back some of those layers around how some have come to understand their ability to act as very individualistic, I would say, even now and so maybe you've found that as well as undergraduates that you teach, but definitely the conception of how we impact on our communities; many of them, who are mostly in their early 20s, they have this sense of engaging individually. But if you can make links to the ways in which they have experienced social agency, it's really powerful.

Bronwyn: And I think it's really essential, because I don't know if you notice in teaching, but when we talk about how you effect political change with students, I noticed a lot that students will know things about the suffragettes or they'll have learned about the Civil Rights Movement in America, and they know about Rosa Parks sitting on the bus, but what they don't know is the huge amount of training and support that happened to enable Rosa Parks to sit on that bus. They think it was an individual who simply sat on that bus. But then, actually, ironically, there's that great story 
about the two young girls that sat on the bus, and did the same protest just a couple of days earlier and were thrown off and nearly killed. And the difference when students understand that Rosa was part of the Highlander School's network of citizenship teaching, that she worked with Martin Luther King, Jr., that she'd been auditioned for the role, and that it was all thought about quite carefully. That another young woman of color who was pregnant, who already was a married mum, was not selected because they decided that there would be too many distracting issues for the media. So it doesn't detract from what Rosa did but there was enormous training and a group of people around her and several attempts at doing this and an infrastructure that would move people who [were boycotting] the buses because of the protest to and from work safely for the next three months. There was a massive network of organization around it.

And that's the thing that's extremely important for students who want to effect change, to understand that you can't do it alone. It is a network of change and I think that in many ways, that's what some of the student leaders are learning in the student school strike. But I'm also anxious that they're doing it at a time when there is such focus on the individual through social media that reaches to the individual in an unmediated way that young people are exposed, as they're learning to conduct themselves politically, to enormous scrutiny and challenge. Several of them have said, you know, "it's very scary to make a statement." You're only 16, you make a political statement, 180,000 followers have liked it and then, you know, what happens in a couple of years when you want to add more nuance and change the view. So it's a very public political learning where there are not many avenues for mistakes, and I think that brings its own burden on young protesters and young activists.

Sara: And we've talked a little bit about that, too, as well in terms of having the importance of recentering youth voice and making sure that young people's voices are part of the public dialogue in meaningful ways, but then also that, you know, are there some tensions around Greta Thunberg, for example, being in a position where, I don't think it's exploitation, but it's sort of like there's some kind of fragile boundaries around that, isn't it?

Bronwyn: So yes and I think tying a movement too closely to one individual and to one concept exposes the movement itself to a lot of risk, because Greta is only human. She's only 18, enormous things will change in her life and in the lives of all those millions of protesting students. And actually, one of the interesting things is in this survey we are doing of children growing up in seven cities around the world (Nissen et al., 2017), is that not a lot of children, outside of a small group of urban students, are even aware of the school strikes, really. So even though they're very visible, they're very digital. They're very photogenic. And they have captured mass media. It's interesting that that depth of penetration is not as great in the developing world, or even regional communities as you'd expect. And the focus on one individual makes it very difficult for students who perhaps don't agree with her or don't identify with her. So it's both a strength of the movement, her articulation, her ability to 
be so visual and so present. And it's a huge weakness and vulnerability of the movement as well.

Sara: You mentioned the CYCLES project. Can you say more about the work that you're doing there and what you're finding?

Bronwyn: That's funded by the UK's Economic and Social Research Council and it's with a larger consortium that I'm a co-investigator with, which is called CUSP, which is the Centre for Understanding Sustainable Prosperity, an interdisciplinary research group of 12 universities led by the ecological economist Tim Jackson. He's based at Surrey, and they are looking at new ways of thinking about ecology and wellbeing in ways that encourage a more sustainable view of prosperity and good living. And so it's interesting because it has science and economics streams, but it also has a very explicit religious philosophies theme that's led by religious leaders like the Archbishop of Canterbury. And then our project is following children growing up in seven world cities. And we came together as a team of researchers, because we had previously worked for a UN study on sustainability, where we looked at older 18 to 24 year olds in 18 countries, and we'd really enjoyed collaborating together. And we were all interested in what the younger adolescent [e.g., 12 to 18 years old] is thinking about their lives and how they are experiencing wellbeing, or not, in their community and what it would take to support more sustainable lives. How many of those families are locked into unsustainable ways of living because they lack city infrastructure, they lack financial options? What are the children's expectations of their lives? What do they like about cities they live in and what do they want to change?

So we did some focus groups and image making with children and young people aged 12 to 24 . Each city has a team of locally based researchers either in a charity or a university that's leading their own local consultation and there's only one city where that hasn't happened. It really doesn't work, I think, when you're not embedded in the communities that the children you are interviewing are growing up, and I think it's really difficult to do nuanced, thoughtful research. You can get high level, but when children and young people are talking to you about the tree that fell down or the debate about the local swimming pool, unless you know that that's been a housing development that was seized by the mayor, it's hard to understand the politics and significance of what they're saying because a lot of children and young people's political realities are embedded in their personal relationships and their family relationships. And so you need local knowledge to understand the wider political and economic significance of something that can seem quite little. Like, for instance, a good example that I learned about was a local primary school that we interviewed in the first edition of the book (Hayward, 2012), the children said that they had protested in the playground about not being able to climb trees. They wanted to be able to climb the really high trees which they've always been able to, but Health and Safety of the school board said they couldn't. So they made placards and they protested and what was very interesting about that was that-I wouldn't have known, except that one of 
our interviewers lives in that particular neighborhood-is that there was a big strike affecting their local supermarket and a lot of the local parents. So many of those children that were striking about not being able to climb trees were observing strikes at home in parents' workplaces, and I wouldn't have been able to make that connection, unless somebody local was doing the research.

Sara: Yeah, that's true. It does matter a lot, having that nuanced local knowledge in this work.

Bronwyn: Yes, because what we sort of forget is that children are learning about their environment from multiple ways. So when I interviewed a small group of school strike leaders, you know, some of them had watched their grandparents striking and protesting over health reforms locally. They were using those lessons directly for how they might effect change on the issue that mattered to them, which was climate.

Sara: It makes me think about how the most activist of my friends grew up in very activist or, you know, highly unionized families and were just immersed in it.

Bronwyn: Louise Chawla said that youth activists and their understanding of power and their interest in protecting the environment grows up usually from their experience with the environment, but I think the bit that's missing that we need to look at is where did they see their models for effecting social change. And because we don't often put those two discussions togetherthe political change and the environmental change-we forget how much our civics and citizenship teaching influences our environmental understanding.

Sara: I feel like that's such a huge theme in the book, what you just said: where did they see their models for effecting social change and how that influences their understanding of environmental ecological citizenship or engagement. And you have the updated version out now.

Bronwyn: Yes, in the significantly revised second edition, we look at how students with teachers, parents, and other activists can learn to take effective action to confront the complex drivers of our climate crisis. And that includes economic and social injustice, colonialism, and racism. Though we haven't done much on racism, and I should have done something more [in the book]. But what I wanted to do was make sure that it wasn't an environmental book at the beginning. This is very frustrating for people to just say, all we have to do is reduce carbon, as if all these other issues are slowing us down, like dealing with colonization. It's not a direct route. The thing is if it were just about reducing carbon, we would have fixed climate change. Because it's not that easy, it's complex layers of issues that have affected out climate change. Climate change is the symptom of multiple social and economic injustices and struggles. Mike Hulme has a depressing take which is probably fair enough, that as we deal with these wicked problems, we're going to shift the problem in new ways. We are always going to have a changing climate. We're just going to get some bits of it more fairly done. But I don't know, I think Covid, just suddenly stopping everything... but anyway. 
Sara: I mean it is interesting to think about how these new global challenges highlight-I don't want to say opportunities but highlight-it's not an opportunity, it's a crisis, but a crisis means a turning point. Right. So yeah, who knows. But it does make me think about what you're saying in your co-authored article on learning from Pacific Small Island Developing States (Hayward et al., 2020). Can you just briefly highlight some of those lessons from the Pacific Small Island climate responses?

Bronwyn: And that was with colleagues and students because they were concerned that there is a narrative that it's too late to take action and that itself becomes a self-fulfilling prophecy, because it's not too late for the Pacific. Every climate change action that happens will make the impact on those communities less. We may not be able to stop rising sea levels now, but we will be able to mitigate some of the worst effects on communities. And also writing that article about thinking about what wellbeing means and how communities support each other through big environmental and social change in the Pacific arose out of my concern listening to teachers that were working in schools in the Pacific expressing frustration that charities and international educators were coming in with programs focused around climate which were very narrow, and increased student anxiety. They were not really related to the issues that the students wanted to deal with or the community. And they were externally donor- or grant-driven so that they weren't accountable to the local community. And so I was interested in documenting, how is it that communities have coped with past existential crises, whether it's slavery or genocide in the Pacific, and how are they addressing the complex changes of climate, given that there have been really major pressures on these communities. HIV, for instance, has had a huge effect on the demographic profile of many Pacific communities. So there are lots and lots of young people and fewer adults now in the population, and that's not necessarily just because of migration for work, but because of previous losses of population. But I also think that that comment that was made by the reviewer for our recent grant proposal that alerted us to the dangers of the assumption that Indigenous communities are all so endlessly resilient that they will be able to cope is important, too. But I think this "beyond science" idea is important here because the scientists who think, you know, the carbon is the problem, don't see the social networks and the religious and the community networks that sustain change. So it's not too late for that. But it needs different kinds of support.

Sara: You mentioned the comment on our recent grant proposal about critical hope and climate change. That there has been some critique of this concept of hope, as you know, is hope what we need? What would you say about that? It seems like it builds on what you're saying here [related to the aforementioned article, Hayward et al., 2020].

Bronwyn: Yeah, I think it is what sustains action and change. And the challenge is agency, you know, the neoliberal effective politics, so long as we've given a lot of emphasis to individual action for change, or even collective action. But you have to find a way to sustain resistance in movements and 
whether you call it hope or whether you call it faith or whether you call that just collaborative solidarity, the concept of the critical hope is not acting in a Pollyanna away believing that good things will happen. It's acting in the face of the knowledge of political inequality, the extreme difficulties that you face, and taking action, anyway. If we don't have that ability to take action, anyway, we are lost.

Sara: A good friend of mine, Amanda Holmes, who is Haudenosaunee Mohawk, talks about how you just keep on keeping on because you're doing it for the generations to come. And you're doing it to honor the ancestors who came before you who did that as well. So you just don't think about whether it's going to be "effective" or not. You just do, because it's part of this genealogy.

Bronwyn: And duty.

Sara: And duty, and long-term sustainability. Like you just-it's part of the ethic of being alive, right, and this is something I think about, too, I don't know, when we were talking before about individual action. I sometimes wonder if we're talking about ethical versus political engagement. That's kind of an aside, but when you were talking about individual actions we take like to make sure that-I compost, and recycle, but I don't necessarily see those as meaningful political forms of engagement, but I see them as ethical forms of engagement.

Bronwyn: And it matters that we do have ethically responsible individuals, but I have been surprised and I haven't done research about it. I'd like to, it's just anecdotal, but I've been surprised how many students say to me that they feel that they can't take political action because they're not recycling or they just don't have keep-cups [reusable cups] for the coffee. But it's just so irrelevant to the big picture whether they use a plastic straw or not. And when our ethical actions become such that it inhibits people from feeling that they can support social movements for change, that's a problem. Because it's too much of a burden. The difficult balance is to recognize that ethical actions have to take place in a social and political context. And that many individuals and whole communities are locked into behaviors that are unsustainable and might seem unethical. But it's unaffordable to do anything else, or simply impossible, or they haven't got the time, or they haven't got the social support. And they shouldn't be beating themselves up, we shouldn't be eroding people for being locked into impossible situations.

Sara: Right, exactly.

Bronwyn: Tim Jackson's done a lot of work on "lock-in." Lots of people have, but particularly in England, low-income communities and women have got really high environmental footprints, because they have to use lots of heating in poorly insulated houses. They've got to take unsustainable forms of transport, because there aren't local bus routes, all those kind of things add up. You know, it's like why would we eat bad food? Because it's nearby and affordable. 
Sara: It's sort of related to the issue of awareness versus infrastructure. Like ethics being something that's contextualized and almost inherited in a way and then also you know, different points of engagement where infrastructure is a different point of engagement, like do I create a compost in my own backyard or do we lobby the city to create these organic waste bin for us-it becomes systemic change where people are much more likely to actually do something if there's the infrastructure in place.

Bronwyn: That's where I think Donella Meadows, a lot of people quote her paper on leverage points [http://donellameadows.org/archives/leveragepoints-places-to-intervene-in-a-system/]. I mean, what actions would get the most traction? Sometimes you can burn up enormous amounts of energy over something that perhaps gets only a little traction, has little change in the system, whereas you can get systemic change by asking the right questions.

Sara: Do we teach that to young people?

Bronwyn: Well, that's what we should be doing in politics. It's very hard to work out. And that's the thing about the local experience of climate is, where do you put your energy? But if it's too localized you're trapped. So you do need national leadership, you do need some international leadership. And it's so interesting. At the moment, because the politics of, you know, who should take leadership over what is not clear at all. It's not clear how we're going to affect political change. We're not even clear what change would entail.

Sara: Yes, there is a lot of uncertainty in the system. I love the way you describe the history of neoliberalism and New Zealand in your book because I don't think a lot of people know that. I mean abroad our international perception of New Zealand, many of us don't realize that New Zealand also was caught up in the neoliberal movement as well, both from, you know, the left and the right, from Labor and National. Some people are saying that we're in a post-neoliberal moment now, and especially in New Zealand. Do you think that's true?

Bronwyn: No, I think we are doubling down [laughs]. I think the beginning of the change is to change the language of aspiration. So the Prime Minister (Jacinda Ardern) talking about being kind is a new set of values on top of being efficient and fair. But being kind is not a political action and has a strong individual responsibility, so being kind alone is not yet a vehicle for social change, but in the pandemic itself, watching the community just stop and prioritize public health over the economy, was amazing, and it will be interesting to see what effect that has on children and young people's political learning. Because it's been an imaginative moment which has changed the rules. For 30 years we prioritized the market and had to maintain it at all costs, and in a matter of three months we prioritized public health and stopped everything. And that's a very remarkable action. And I think having watched how just small-scale political actions have big reverberations for children's learning of change-I'm really interested in what effect that will have. So I don't think we are out of the neoliberal moment, but I think that it's expanded people's imagination about doing something different; what will 
happen next matters. Do we double down on deeper nationalization, stronger fear of the outside, do we increase private sector spending and reduce debt at the cost of public services? If we do that, I think we will be going backwards. We know that we've gone backwards in most countries on almost all the sustainable development goals. And I think that income inequality gaps will have grown hugely in New Zealand, but there is a whole generation of children coming into the political process, who have just seen something quite remarkable happen.

Sara: I love that language- - an imaginative moment which changed the rules." If not, at least for a short time. Hopefully, it has a long lasting impact, especially on young people.... I don't know how much of this you can speak to, but just, one of the things you and I have talked about is the notion of how to best communicate the impact of climate change to the public. And I think, also to young people in the context of growing eco-anxiety.

Bronwyn: It's very hard, I'm very anxious about the way in which we talk about urgency and emergency. Because of the democratic implications of declaring a state of emergency, meaning that you suspend normal decisionmaking and normal inclusion. And this idea that these decisions are urgent and have to be made is quite monolithic and yes, we have to take some urgent action, but we're not going to have one action that's going to fit everything anyway. And it's very hard to think about how to convey that. We need to have far reaching changes without disempowering or creating anti-democratic responses that then risk stripping kids of a democratic future as well as a right to a sustainable one. And that's the part that worries me always.

Sara: Such a good point. I've talked with you before about my own daughter who is learning about climate change and ecological sustainability in primary school. And the strategies that she's come up with for fighting climate change is "stop driving," which, you know, she has no control over, yes, yes. Okay. "Stop poaching" was another one her list of notes. It's something I think about a lot, how to teach it in ways that I think honor the kind of realities that we're facing, that are undeniable realities, but at the same time, don't make people feel completely hopeless, or helpless.

Bronwyn: And not make the situation worse.

Sara: But it's such a good point about, well, if we say it's an emergency, then what does that mean for democracy?

Bronwyn: Yeah, but I'm fighting a lone battle on this one. Now it's increasingly harder and harder. Now I see the UN's been using the term, emergency, I just think, oh bugger it, we really shouldn't be using that language, but anyway.

Sara: Well, Bronwyn, that's all I have. And I jumped around but we got through actually all of these questions.

Bronwyn: I feel honored to know you, Sara, it's been lovely. It's like an extension of my life having somebody I can rave with about this stuff. 
Sara: Thanks so much for doing this interview because like I said, these are questions that I've always wanted to ask you more about. I'm so grateful to know you, Bronwyn. Thank you so much for your time and generosity.

\section{REFERENCES}

Hayward, B. (2012). Children, citizenship and environment: Nurturing a democratic imagination in a changing world. Routledge.

Hayward, B. (2020). Children, citizenship and environment:\# SchoolStrike Edition. Routledge.

Hayward, B., Salili, D. H., Tupuana'i, L. L., \& Tualamali'i', J. (2020). It's not “too late": Learning from Pacific Small Island Developing States in a warming world. Wiley Interdisciplinary Reviews: Climate Change, 11(1), e612.

Hulme, M. (2009). Why we disagree about climate change: Understanding controversy, inaction and opportunity. Cambridge University Press.

Hulme, M. (2021). Climate change. Routledge.

Milne, A. A., \& Shepard, E. H. (1994). The complete tales of Winnie-the-Pooh. Penguin.

Nissen, S., Aoyagi, M., Burningham, K., Hasan, M., Hayward, B., Jackson, T., Jha, V., Lattin, K., Mattar, H., Musiyiwa, L., Oliveira, M., Schudel, I., Venn, S., \& Yoshida, A. (2017). Young lives in seven cities-A scoping study for the CYCLES project (CUSP Working Paper No. 6). Guildford: Centre for the Understanding of Sustainable Prosperity.

Open Access This chapter is licensed under the terms of the Creative Commons Attribution 4.0 International License (http://creativecommons.org/licenses/by/4.0/), which permits use, sharing, adaptation, distribution and reproduction in any medium or format, as long as you give appropriate credit to the original author(s) and the source, provide a link to the Creative Commons license and indicate if changes were made.

The images or other third party material in this chapter are included in the chapter's Creative Commons license, unless indicated otherwise in a credit line to the material. If material is not included in the chapter's Creative Commons license and your intended use is not permitted by statutory regulation or exceeds the permitted use, you will need to obtain permission directly from the copyright holder. 